\title{
EVALUATION OF NUTRITIONAL COMPOSITION AND SENSORY PROPERTIES OF CHEESE, CHEESE SPREADS AND TRADITIONAL BUTTER FROM SLOVAK PRODUCTION
}

\author{
Silvia Jakabová, Lucia Benešová, Miroslav Kročko, Peter Zajác, \\ Jozef Čapla, Adam Partika, Jozef Golian, Jana S̆tefániková
}

\begin{abstract}
Cheese production is associated with the analysis of its nutritional composition as well as with the sensory evaluation of the acceptance of the products. The paper is aimed at the determination of basic chemical parameters such as the content of proteins, fat, dry matter, salt and, $\mathrm{pH}$ and also on the evaluation of sensory properties of hard cheeses by the sensory panel. The GC-MS analysis of cheeses, cheese spreads, and traditional butter was performed to evaluate the aroma profile of the dairy products analyzed. The dry matter in the analyzed cheeses varied between 56.75 and $71.83 \%$, the fat content varied from 18.73 to $30.83 \%$, and the salt from 1.21 to $2.61 \%$. The presence of proteins was found between 27.76 and $32.61 \%$ and the $\mathrm{pH}$ of the cheeses ranged from 5.21 to 6.01. The results of the sensory analysis were processed using a PCA map. The results showed that sample no. 5 was rated within all attributes as the best. Sample 3, 2, and 1 followed. Sample 4 received the lowest score. The volatile aromatic compounds that contribute to a taste perception were analyzed by GC-MS in dairy products. The aroma profile was built by the volatile compounds that belonged to chemical families of alcohols, aldehydes, ketones, esters, amides, amines, imines, and terpenes. In particular, cheeses contained mostly alcohols (3-methyl-1-butanol), aldehydes (3-methylbutanal and benzaldehyde), and ketones (acetoin, 2,3,3-trimethylcyclobutanone, 2-heptanone, 2,3butanedione, acetone, 2-butanone, 2-nonanone, 2- pentanone). The spreads most often contained alcohols (represented by 2-methyl-1-butanol, 3-methyl-1-butanol and cyclopropane-1,2,3-d3-methanol), aldehydes (2-methylbutanal, 3-methylbutanal, benzaldehyde) and ketones (acetoin, 2-heptanone, 2-pentanone, 2-butanone and 2,3-butanedione).
\end{abstract}

Keywords: cheese; cheese spread; butter; chemical composition; sensory analysis; aroma profile

\section{INTRODUCTION}

Milk and dairy products such as cream, butter, yogurt, kefir, and cheese have been consumed around the world for millennia. Milk and other dairy products are indispensable for daily life, and their aroma characters are unique and provide great value in many processed foods, candies, cookies, and others (Tamura et al., 2021). Due to the diverse options in ingredients, recipes, and processing conditions, manufacturers have many possibilities for producing cheeses and spreads with different physicochemical properties, leading to different flavours, functional properties, and uses according to consumer preferences (Hamad and Ismail, 2013; Visioli and Strata, 2014). The nutritional composition of the cheese varies depending on the type of cheese, but in general, cheeses are high in fat, saturated fat, and cholesterol. The protein content of cheese ranges from 3 to $40 \%$ (O'Callaghan, O'Connor and O'Brien, 2017). An important component of cheese is also salt, which has three main functions in the cheese: it acts as a preservative, contributes directly to the aroma, and is a source of sodium in the diet. Together with the required $\mathrm{pH}$, water activity, and redox potential, the salt helps to preserve the cheese by minimizing degradation and preventing the growth of pathogens (Guinee, Carić and Kalab, 2004). The raw flavour is obtained from a wide variety of compounds that results from the hydrolysis or metabolism of carbohydrates, proteins, and fats, along with compounds added during processing, ripening, or directly from milk (Kilcawley, 2017; Le Quéré, 2011). The important role in the development of dairy product aroma play especially the degradation of proteins (caseins) that leads to the formation of the most important flavour components which contribute to the sensory perception of dairy products. Caseins are degraded into peptides and amino acids and the latter are major precursors for volatile aroma compounds (Smit et al., 2005). The volatiles responsible for the typical aroma of cheese is produced mainly by lipolytic and proteolytic pathways and by the 
metabolism of lactose, lactate, and citrate (Bertruzzi et al., 2018). Perception of cheese flavour is due to the combined detection of aroma and taste compounds present in cheese by their respective sensory receptors. The flavour of the cheese is related to milk quality, processing operation, microbial activity, and added flavouring agents such as spices and herbs (El-Sayed and Youssef, 2019; Smit et al., 2005; Bertruzzi et al., 2018; Drake, 2007).

The basic nutritional composition of the cheese can be determined by traditional chemical reference methods for measuring fat (e.g. ether extraction), protein content (Kjeldahl), moisture (gravimetric determination by oven drying), and salt (titration with silver nitrate according to Volhard), which are accurate but also too slow and impractical for rapid analyzing of large numbers of cheese samples in laboratories. At present, fast process and more cost-effective methods are used, such as near-infrared spectrometry (NIR), mid-infrared spectroscopy (MIR), or near-infrared transmittance spectroscopy (NIT) for the simultaneous determination of multiple chemical parameters (fat, protein, salt, and moisture) (Margolies and Barbano, 2018; Alinovi et al., 2019; Visconti et al., 2020; Madalozzo et al., 2015; Manuelian et al., 2017).

Aroma profile and volatile compounds analysis in food is possible by various olfactometry methods such as Charm analysis, AEDA (aroma extract dilution analysis), odour unit, and other methods (Tamura et al., 2021). In the last decades, volatile compounds responsible for the aroma were identified with the use of gas chromatography-based techniques. The volatile profile of cheese and dairy products is determined especially by an electronic nose (e-nose), gas chromatography coupled with mass spectrometry (GC$\mathrm{MS})$. E-nose is an odour detection device using an array of sensors (Delgado-Rodríguez et al., 2012; Schlossareck and Ross, 2019). Electronic nose with sensors is used in many industries and for various applications such as quality control, process monitoring, shelf-life evaluation, origin or authenticity assessment (Buratti et al., 2018; Li et al., 2017). Gas Chromatography-Mass Spectrometry (GC-MS) is the reference method in the analysis of volatile organic compounds (VOCs) in the field of environmental, food, flavour and fragrance, medical and forensic sciences. The technique allows determining volatile compounds present at trace levels that have a low perception threshold but significantly contribute to the flavour profile of food (Bertruzzi et al., 2018).

Dairy products and their aroma profile and flavour have been intensively studied. Niimi et al. (2014) reported that the same aromatic active compounds can be present in several types of cheese however they usually differ by varying the amount of a particular ingredient in such a product.

The paper aims to evaluate selected chemical and physical parameters and sensory properties of cheeses and characterization of the aroma profile of cheeses, cheese spreads, and traditional butter of Slovak origin.

\section{Scientific Hypothesis}

Cheeses were studied to evaluate the consistency of chemical composition, acceptability of cheeses by a sensory panel. An exploration of cheeses, cheese spreads, and traditional butter by GC-MS was performed to confirm the differences in the aroma profile.

\section{MATERIAL AND METHODOLOGY}

\section{Samples}

Cheeses and cheese spreads and butter were obtained from cheese producer Dubník, the Slovak Republic in three different batches. Samples of five types of hard cheese differ in flavouring spices and length of ripening. Hard cheeses were analyzed for basic physical and chemical composition by NIR and sensory panel. 11 samples of dairy products (including above mentioned 5 types of hard cheese, 5 types of cheese spreads, and one type of traditional butter) differed in the technological process of their production ). All 11 samples were analyzed by GC-MS for aroma profile determination. The hard cheese samples were analyzed by NIR and sensory panel.

All analyzed samples are characterized as follows: no. 1 hard cheese with chili flakes „L'ahké pierko s čili“; no. 2 6 months rippening hard cheese „Kryštálová Kamenica“; no. 3 - 3 months rippening hard cheese „Sýta Rubaň“; no. 4 - hard cheese with chives „Jemný Dubník pažítka“; no. 5 - hard cheese with 4 spices „Lahké pierko 4 korenia“; no. 6 - cheese spread with smoked cheese „Syrová nátierka $\mathrm{s}$ údeným syrom“; no. 7 - cheese spread with onion „Syrová nátierka sladká cibul'ka“; no. 8 - cheese spread with hot paprika „Syrová nátierka pálivá paprika“; no. 9 - cheese spread with sweet paprika „Syrová nátierka dolniacka paprika“; no. 10 - cheese spread with emmental cheese „Syrová nátierka Ementálček“; no. 11 - traditional butter „Tradičné maslo“.

\section{Chemicals}

The analyses did not require special chemicals. We used deionized water and ethanol (96\%, p.a., nondenatured, Centralchem Ltd., Slovakia) for washing the equipment.

\section{Animal and Biological Material}

No animal and biological material was used.

\section{Instruments}

NIR spectrometer, type MPA (Bruker Optik GmbH, USA) was applied for the determination of the basic chemical composition of cheeses. Selected chemical parameters (dry matter, fat, salt, $\mathrm{pH}$, proteins) were measured at the AgroBioTech SPU research center. The cheese samples were homogenized into a fine powder, then transferred to a Petri's dish (type Duraplan) and placed in the apparatus. The NIR instrument was calibrated by O.K. SERVIS BioPro, Ltd. for hard cheeses in the range as follows: fat $(5$ - 43.6\%), $\mathrm{NaCl}(0.04-2.85 \%)$, proteins $(13.6-37.10 \%)$, dry matter $(24.2-72.6 \%)$ and $\mathrm{pH}(4.93-6.35)$.

The aroma profile was analyzed by gas chromatography coupled to mass spectrometry (GC-MS). Agilent 7890B gas chromatograph coupled with an Agilent 5977A mass spectrometer (Agilent Technologies Inc., Palo Alto, CA, USA) was used. Separation was performed by a DBWAXms column $(30 \mathrm{~m} \times 0.32 \mathrm{~mm} \times 0.25 \mu \mathrm{m}$; Agilent Technologies) working with the temperature program and MS conditions according to Sádecká et al. (2014). Identification of the compounds was performed by matching the measured peaks with Kovats' retention indices with NIST library (The National Institute of Standards and Technology Library) by software Alpha Soft V14 (Alpha M.O.S.) (Štefániková et al., 2019). 


\section{Description of the Experiment Sample preparation:}

The samples were used after cutting/homogenization into appropriate size and by adjusting the temperature (for NIR and sensory panel analysis).

NIR analysis required homogenization of the cheese samples and then the samples were put into glass Petri's dishes (type Duraplan) in amount $20 \mathrm{~g}$.

For GC-MS analysis, the cheese samples were cut into small pieces. $4 \mathrm{~g}$ of each sample (cheese, spread, or butter) was weighed into clean $20 \mathrm{~mL}$ headspace vials covered by a magnetic cap with a septum. The samples prepared were stirred at $50{ }^{\circ} \mathrm{C}$ or 15 minutes on a shaker included as a part of the GC headspace autosampler (Combi Pal, Alpha M.O.S.).

Sensory analysis was performed in the sensory laboratory. The equipment of the sensory laboratory and the course of the evaluation were performed based on the ISO 8589 (2007) standard. The cheese analysis involved 6 experienced experts. The cheese temperature was adjusted to $10{ }^{\circ} \mathrm{C}$ and the room temperature was $21{ }^{\circ} \mathrm{C}$. The organoleptic properties of the individual samples were evaluated using a $1-9$ point test $(1-$ insufficient to 9 - very intense). The sensory panel evaluated the attributes: appearance, overall odour, aroma odour, consistency, overall taste, flavour, overall acceptability.

Number of samples analyzed: 3 batches of 11 samples Number of repeated analyses: 3 times repeated measurements

Number of experiment replication: 2 parallel replications

\section{Statistical Analysis}

Statistical analysis was performed in the program Excel with XLSTAT (vs. 2020.3.1) statistical software for Excel. Chemical parameters were analyzed with descriptive statistics (means, standard deviations, minimum, maximum values) and results were visualized in boxplots. Data from the sensory panel were tested for normality with the Shapiro-Wilk test on a significance level $p=0.05$. A graphical evaluation was performed with the use of principal component analysis (PCA) and visualized in a biplot map, which presents individual observations, as well as variables examined in one plot. Data obtained in GC-MS analysis - a type of chemicals and area percentage of aromatic compounds were visualized in XLSTAT as a heat map. The columns of the data matrix were re-ordered according to the hierarchical clustering result, putting similar observations close to each other. The result is a heat map with a double dendrogram in a vertical and horizontal position.

\section{RESULTS AND DISCUSSION}

The results obtained can be divided into three parts chemical composition, sensory evaluation, and aroma profile.

\section{The basic chemical composition}

The chemical composition results are summarized in Table 1 and Figure 1. The dry matter in the analyzed cheeses ranged from 54 to $68.4 \%$. In general, it can be stated that cheeses containing herbs had a lower salt content compared to ripening cheeses such as "Kryštálová Kamenica” or "Sýta Rubaň".

The fat content ranged from 17.42 to $30.88 \%$ and the salt from 1.2 to $2.1 \%$. Proteins accounted for 27.4 to $32.43 \%$. The acidity of the cheeses, characterized by a $\mathrm{pH}$ value, was in the range of 5.04 to 6.03. The highest values in the most of parameters were determined in Sýta Rúbaň cheese, except for the protein content.

The lowest values of these parameters were found in cheese with 4 types of spices, again except for protein content. A visual expression of the consistency of the individual cheese chemical composition data is shown in Figure 1. In our case, the results indicate the consistency of the chemical composition of the samples over time. Since the data were collected from 3 series of measurements during the 3 months (the cheese producer provided samples at monthly intervals), the results reflect the stability of the chemical composition of the products over time. As can be seen in the case of dry matter content, the closest data were measured for the "Kryštálová Kamenica" and "Lahké pierko s čili" cheeses. "Kryštálová Kamenica" is a cheese that has been ripening for 6 months, therefore the composition of this cheese becomes stable. Cheeses such as "Sýta Rubaň" and "Lahké pierko 4 korenia" had a higher dry matter content, which may be related to seasonal changes in milk parameters. In the case of fat content, the closest data were observed in the "Sýta Rúbaň" cheese and the largest variance was recorded in the "Lahké pierko 4 korenia". The salt as a parameter showed a relatively constant proportion in cheeses such as "Jemný Dubník pažítka", "L'ahké pierko s čili" and "Lahké pierko 4 korenia". We found the highest variability of the salt content values in the "Sýta Ruban̆" cheese. The $\mathrm{pH}$ values were most balanced in the "Kryštálová Kamenica” and "Jemný Dubník pažítka”. On the other hand, "L'ahké pierko 4 korenia" had the highest variance in $\mathrm{pH}$ values. In the protein content, we recorded the most consistent data for all analyzed cheeses.

Different types of cheese were analyzed in literature to evaluate basic chemical composition. Ricotta cheeses were analyzed by Madalozzo et al. (2015) NIR method for protein and fat content. The average fat content was $10.63 \%$, protein $12.37 \%$, and moisture $70.23 \%$. Margolies and Barbano (2018) analyzed Cheddar cheeses using the MIR technique. The average fat content was $34.0 \%$, the protein content $24.0 \%$, the moisture content $36.82 \%$ and the salt 1.8\%. Manuelian et al. (2017) analyzed commercial cheeses using the NIT technique. The moisture, fat, and protein contents averaged $43.24 \pm 0.97 \%, 27.24 \pm 0.47 \%$, and $24.87 \pm 0.54 \%$. Jo et al. (2018) analyzed the sensory and chemical properties of Gouda cheeses. All cheeses had a water content of less than $45 \%$, a fat content of more than $46 \%$, and a $\mathrm{pH}$ value in the range of 4.9 to 5.6. The salt content of the cheese differs significantly from the type of cheese, ranging from about $0.5-0.7 \%$ in acidic cottage cheese and Emmental cheeses to about 4-6\% in pickled cheeses such as Domiati and feta (Guinee, 2004).

Kuflu cheese, a Turkish mould-ripened variety was studied by Hayaloglu et al (2008). This type of cheese was characterized by moisture content $49.97 \%, 12.18 \%$ fat content, $37.84 \%$ total protein contents, and $\mathrm{pH}$ 6.29. Our results corresponded most to the chemical parameters in ripening Cheddar cheeses. 
Table 1 Chemical composition of cheese samples.

\begin{tabular}{|c|c|c|c|c|c|c|c|c|c|c|c|}
\hline & \multirow[t]{2}{*}{ Sample } & \multicolumn{2}{|c|}{$\begin{array}{c}\text { Dry matter } \\
(\%)\end{array}$} & \multicolumn{2}{|c|}{$\begin{array}{l}\text { Fat } \\
(\%)\end{array}$} & \multicolumn{2}{|c|}{$\begin{array}{c}\mathrm{NaCl} \\
(\%)\end{array}$} & \multicolumn{2}{|c|}{ pH } & \multicolumn{2}{|c|}{$\begin{array}{c}\text { Proteins } \\
(\%)\end{array}$} \\
\hline & & $\overline{\mathbf{x}}$ & $S D$ & $\overline{\mathbf{x}}$ & $S D$ & $\overline{\mathbf{x}}$ & $S D$ & $\overline{\mathbf{x}}$ & $S D$ & $\overline{\mathbf{x}}$ & $S D$ \\
\hline 1 & Lahké pierko s čili & 60.65 & 0.42 & 20.56 & 0.21 & 1.72 & 0.07 & 5.61 & 0.02 & 31.75 & 0.01 \\
\hline 2 & Kryštálová Kamenica & 65.98 & 0.05 & 25.06 & 0.67 & 1.90 & 0.11 & 5.86 & 0.02 & 32.61 & 0.18 \\
\hline 3 & Sýta Rúbaň & 71.83 & 3.43 & 30.83 & 0.05 & 2.61 & 0.51 & 6.01 & 0.02 & 31.22 & 0.06 \\
\hline 4 & Jemný Dubník pažítka & 62.66 & 0.80 & 29.02 & 0.40 & 1.45 & 0.04 & 5.50 & 0.06 & 27.76 & 0.36 \\
\hline 5 & Lahké pierko 4 korenia & 56.75 & 2.75 & 18.73 & 1.31 & 1.21 & 0.01 & 5.21 & 0.17 & 30.15 & 0.09 \\
\hline
\end{tabular}

Note: $\overline{\mathrm{x}}$ - mean, $S D$ - standard deviation.

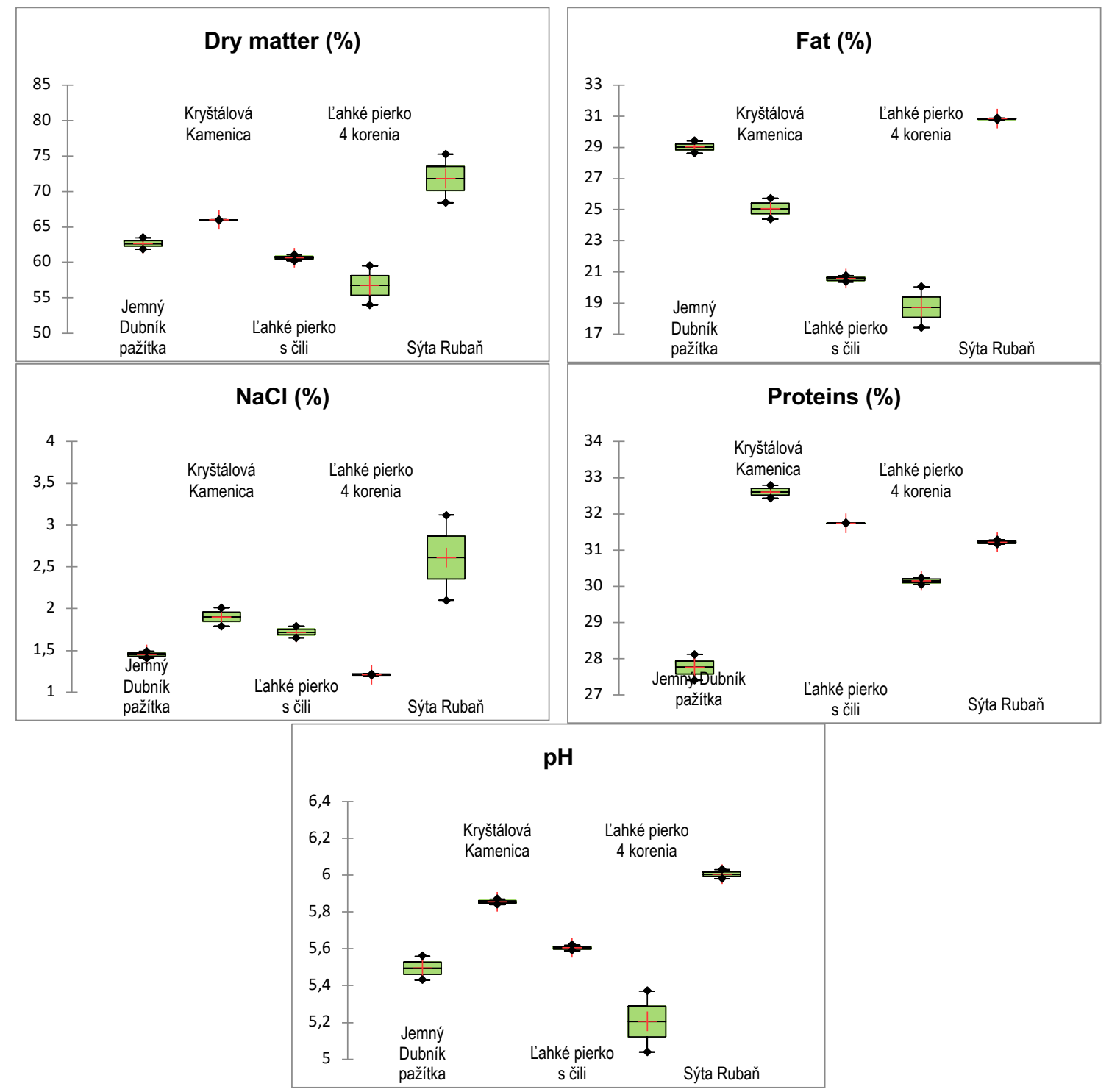

Figure 1 Boxplots of chemical composition variability. Note: + Mean $\bullet$ Minimum/Maximum.

\section{Sensory analysis}

Sensory analysis was performed in the sensory laboratory. Trained sensory panels are important tools for assessing the quality of food and non-food products (Tomic et al., 2010). Sensorial features of cheese are more or less a consequence of the combined actions of all steps involved in its processing (Kongo and Malcata, 2015). The organoleptic properties of the individual samples were evaluated using a $1-9$ point test ( $1-$ insufficient to 9 - very intense). The sensory panel evaluated the attributes: appearance, overall aroma, aroma odour, consistency, overall taste, flavour, overall acceptability. The data obtained from the sensory evaluation were processed and statistically tested by the Shapiro-Wilk test for normality at a significance level of $\mathrm{P}=0.05$. A principal component analysis (PCA) was used to determine element variability and visualization of sensory analysis data. The result is PCA biplot (Figure 2). For a better interpretation of the results obtained using the statistical method of analysis of the main components, we used visualization using the so-called biplot. This PCA map represents a biplot that shows simultaneously our observations as well as the variables examined in a single graph. The coordinate axes ( $\mathrm{x}$ and $\mathrm{y}$ ) of the biplot explain $79.52 \%$ of the total variation of observation. 
This type of graph allows a better interpretation of the share of individual characteristics in the main components. A PCA biplot shows both PC scores of samples (dots) and loadings of variables (vectors). The further away these vectors are from a PC origin, the more influence they have on that PC.

In our biplot, the most important variables in the sensory evaluation were overall acceptability and appearance, almost no influence had consistency and aroma odour.

The results of the sensory analysis (Figure 2) showed that sample no. 5 "Lahké pierko 4 korenia" was rated within all attributes as the best. Sample 3, 2, and 1 followed. Sample 4 "Lahké pierko s pažítkou" received the lowest score. Toro, Valencia, and Molina (2016) evaluated nutritional parameters and sensory features of processed cheese. For the development of this type of food product, it is necessary to consider nutrition value for different groups of people and its versatility and ease of consumption.

\section{Aroma profile}

The GC-MS method is often used to characterize the aromatic profile of dairy products. We have found the presence of the following aromatic compounds. The volatile compounds that were identified belong to several chemical groups: alcohols, aldehydes, ketones, carboxylic acids, esters, amides, amines, imines, and terpenes (Table 2a and 2b). Data obtained by GC-MS analysis and area percentages were visualized by heat map (Figure 3). The vertical dendrogram represents volatile compounds in the samples and the horizontal dendrogram the reordered samples. The

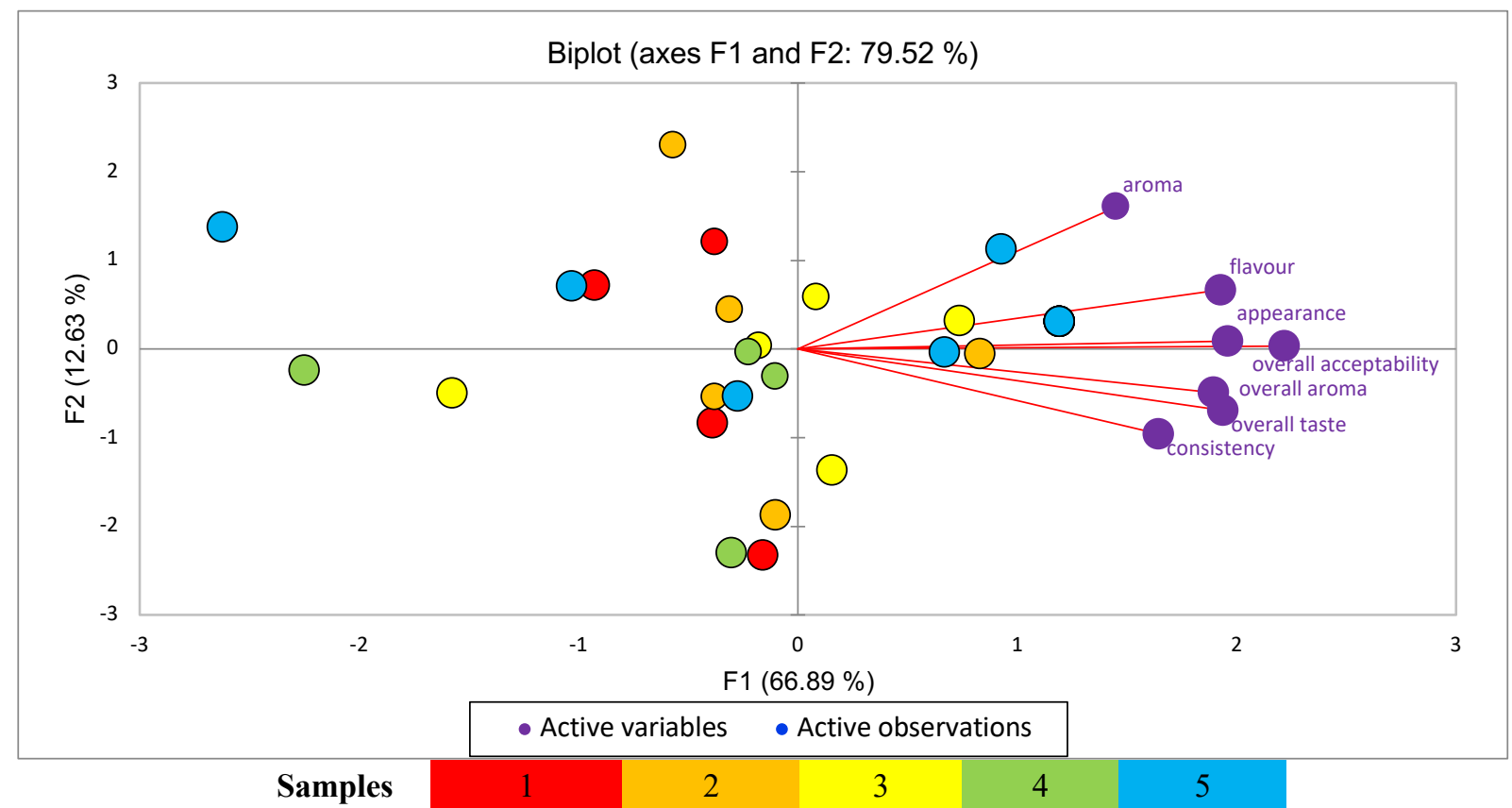

Figure 2 Sensory analysis by the sensory panel. Note: no. 1 - hard cheese with chili flakes „L'ahké pierko s čili“; no. 2 - 6 months rippening hard cheese „Kryštálová Kamenica“; no. 3 - 3 months rippening hard cheese „Sýta Rubaň“; no. 4 - hard cheese with chives „Jemný Dubník pažítka“; no. 5 - hard cheese with 4 spices „Lahké pierko 4 korenia“.

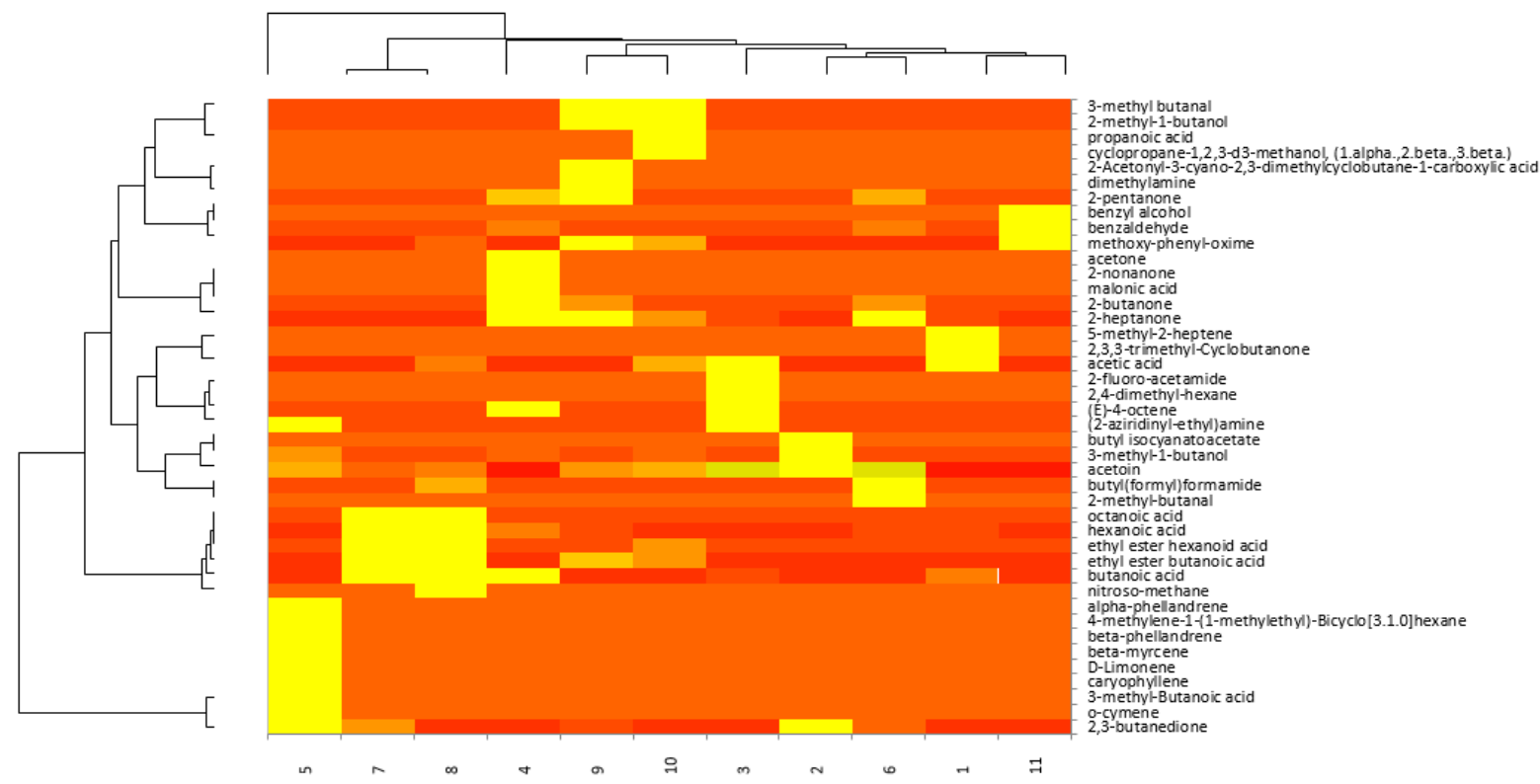

Figure 3 Heat map. 
heat map reflects the range of area percentages as well as the proportion of specific volatile aromatic compounds in the individual samples. The clustering showed that the compounds are divided into four groups (left dendrogram) according to the observed similarities. The pattern inside the map shows the groups of compounds described above as follows: the first cluster is represented by the compounds 5methyl-2-heptene to 2-methyl-butanal, the second cluster is represented by compounds from acetone to propanoic acid. The third group can be clearly distinguished by the presence of 2-pentanone to butanoic acid. This means agglomeration appears to have moderate amounts of most of the compounds. Compounds from D-limonene to 2,3butanedione represent group four. Horizontal clustering revealed the fact that almost no similarities were observed between the samples, based on the composition of the aroma profile and the amount of volatiles.

\section{Cheese aroma profile}

Aldehydes (specifically 3-methylbutanal and benzaldehyde) were an important group of volatile compounds in cheeses with a presence in several samples. Due to their low odour detection thresholds, these compounds contribute significantly to the aroma features of the cheeses. Among the carbonyl compounds, ketones were also represented, namely acetoin, 2,3,3-trimethylcyclobutanone, 2-heptanone, 2,3-butanedione, acetone, 2butanone, 2-nonanone, 2-pentanone. Alcohols also have a low odour detection threshold, which gives dairy products herbal, woody and fatty tones. We identified alcohols represented by 3 -methyl-1-butanol in our cheese samples. Terpenes (specifically $\beta$-phellandrene, $\alpha$-phellandrene, $\beta$ myrcene, o-cymene, D-limonene, and caryophyllene) were also identified in sample 5 (cheese "Lahké pierko 4 korenia") to confirm the spicy aroma of the sample. Carboxylic acids such as acetic acid, butanoic acid, caproic acid (hexanoic acid), heptanoic acid, malonic acid, and 3methyl-butanoic acid were present in the cheese samples.

Sample 1 with chive flavour had the largest proportion of acetic and butyric acid. In sample 2 with chili flavour, acetoin was present in the highest concentrations, followed by 3-methyl-1-butanol, 2,3-butanedione. Sample 3 was characterized by the highest proportion of acetoin and acetic acid, followed by (2-aziridinylethyl)amine. In sample 4 (Kamenica matured Parmesan-style cheese) the most abundant was butanoic acid, followed by acetone.

In the last sample were dominant 2,3-butanedione, (2aziridinylethyl) amine, acetoin, D-limonene, followed by terpenes such as $\alpha$-phellandrene, caryophyllene, o-cymene, $\beta$-phellandrene, which originated from the addition of spices.

Cheddar cheeses were analyzed on aroma profile by GCMS by the authors Chen et al. (2020). They found fortynine flavour compounds in the samples, including 11 acids, 5 aldehydes, 8 alcohols, 8 ketones, 9 esters, 3 aromatic hydrocarbons and heterocyclic compounds, and 4 other compounds. The active ingredients were mainly aldehydes (2-methylbutanal, 3-methylbutanal, benzaldehyde), ketones (2-heptanone, 2-octanone), carboxylic acids (butyric, isovaleric acid, octanoic acid, n-decanoic acid, hexanoic acid), and esters (ethyl hexanoate, ethyl acetate, ethyl butyrate, and butyl acetate). The authors identified, according to the value of the aroma intensity (AI values), the compounds with the highest aromatic activity in the cheese. Several compounds have relatively high aroma intensity values such as butyric acid (cheesy/rancid), ethyl acetate (fruity/sweet), 2-heptanone (cheesy/spicy/fruity), ethyl butyrate (fruity/sweet), benzaldehyde (almond), 3methylbutanal (nutty/malty), 2-methylbutanal (nutty/chocolate), and 3-methylbutanoic acid (cheesy/sweaty/rancid). Of these, the odours of 3methylbutanal and 2-methylbutanal were rated by the sensory evaluation panel as pleasantly nutty, and the almond odour imparted by benzaldehyde was also considered to be a good nutty flavour. Štefániková et al. (2019) analyzed by GC-MS traditional slovak „Parenica“ cheese. A Parmesan and parmesan-style cheese aroma were studied by Barbieri et al. (1994), Moio and Addeo (1998). The backbone of Grana Padano cheese aroma seemed to consist of carboxylic acids and 14 potent neutral odourants imparting fruity, green, nutty, and coconut notes. The authors reported that the concentration of volatile components responsible for the fruity and green notes was inversely proportional to the length of ripening, whereas the concentration of volatile agents with spicy, nutty, and earthy notes tended to increase during maturation. Bryndza cheese aroma profile was studied by Sádecká et al. (2014). The overall aroma of Bryndza cheese was found to be formed by the following volatile components: esters, alcohols, aldehydes, ketones, fatty acids, and hydrocarbons. Nineteen of twenty-seven aroma-active compounds were identified. Mascarpone cheese aroma was analyzed by Capozzi et al. (2020) and the volatile compounds contributing to aroma were classified into 9 chemical classes (9 ketones, 5 alcohols, 4 organic acids, 3 hydrocarbons, 2 furans, 1 ester, 1 lactone, 1 aldehyde, and 1 oxime).

The most abundant compounds were ketones (especially 2-heptanone and 2-pentanone), then 2-propanone, 2nonanone, 2-butanone, 1-pentanol, 2-ethyl-1-hexanol, furfural, and 2-furan methanol. Thomsen et al. (2014) studied different French commercial cheeses belonging to the same type: non-cooked semi-hard cheeses, including famous types like French Port Salut or Gouda. The volatiles found in the samples belonged to sulfur compounds (e.g. dimethyl disulfide, described as cauliflower, garlic flavour), alcohols (3-methyl butane-1-ol was found in the greatest amount and this alcohol has been described in cheeses with a fruity aroma (Pérès, Viallon and Berdagué, 2001), aldehydes (e.g. 3-methylbutanal, responsible for cheesy aroma), ketones (the most abundant ketone was 3hydroxybutan-2-one or acetoine, perceived alone with a dairy aroma), carboxylic acids (the most abundant carboxylic acid was 3-methylbutanoic acid, described as a potent odourant in goat cheese flavour (Poveda et al., 2008), esthers (e.g. ethyl acetate and ethyl propanoate), lactones and furans.

Our results corresponded more closely with analyzes of the Cheddar cheeses, which belong to ripening cheeses, and therefore we also found these compounds in our samples of ripening cheeses. The similarities in dominant compounds were also found with non-cooked semi-hard cheeses. 
Table 2a Cheese aroma profile.

\begin{tabular}{|c|c|c|c|c|}
\hline \multirow{2}{*}{ No. } & \multirow{2}{*}{ Compound } & \multicolumn{2}{|c|}{ Percentage area } & \multirow{2}{*}{ Aroma } \\
\hline & & $\overline{\mathbf{x}}$ & $S D$ & \\
\hline \multirow{6}{*}{1.} & acetic acid & 20.82 & 1.86 & sour fruity \\
\hline & butanoic acid & 5.41 & 0.74 & unpleasant \\
\hline & 2,3,3-trimethyl-cyclobutanone & 1.99 & 1.27 & unknown \\
\hline & 5-methyl-2-heptene & 1.64 & 0.46 & nutty \\
\hline & 2-heptanone & 0.76 & 0.20 & cheesy \\
\hline & hexanoic acid & 2.85 & 0.40 & fatty \\
\hline \multirow{5}{*}{2} & 2,3-butanedione & 12.68 & 3.16 & buttery \\
\hline & 3-methyl-butanal & 3.94 & 1.67 & aldehydic \\
\hline & acetoin & 26.3 & 3.48 & buttery \\
\hline & 3-methyl-1-butanol & 9.79 & 2.13 & fermented \\
\hline & butyl-isocyanatoacetate & 3.76 & 0.26 & sulfuric \\
\hline \multirow{8}{*}{3} & (2-aziridinylethyl)amine & 16.46 & 6.58 & unknown \\
\hline & acetic acid & 22.28 & 2.09 & sour fruity \\
\hline & 2-fluoro-acetamide & 2.35 & 1.17 & unknown \\
\hline & acetoin & 20.52 & 17.50 & buttery \\
\hline & butanoic acid & 1.30 & 0.20 & cheesy \\
\hline & 2,4-dimethyl-hexane & 0.58 & 0.12 & unknown \\
\hline & (E)-4-octene & 1.28 & 0.21 & unknown \\
\hline & 2-heptanone & 0.65 & 0.14 & cheesy \\
\hline \multirow{12}{*}{4} & acetone & 11.15 & 1.84 & fruity \\
\hline & 2-butanone & 13.53 & 8.02 & ethereal \\
\hline & malonic acid & 0.76 & 0.04 & odourless \\
\hline & malonic acid & 1.11 & 0.65 & odourless \\
\hline & 2-pentanone & 4.44 & 0.14 & fruity \\
\hline & 3-methyl-1-butanol & 0.45 & 0.21 & fermented \\
\hline & butanoic acid & 17.38 & 1.84 & cheesy \\
\hline & (E)-4-octene & 0.84 & 0.19 & unknown \\
\hline & 2-heptanone & 8.78 & 2.19 & cheesy \\
\hline & benzaldehyde & 0.66 & 0.25 & almond \\
\hline & hexanoic acid & 8.45 & 0.38 & fatty \\
\hline & 2-nonanone & 3.42 & 0.84 & fruity \\
\hline \multirow{13}{*}{5} & (2-aziridinylethyl)amine & 14.36 & 1.94 & unknown \\
\hline & 2,3-butanedione & 18.73 & 6.34 & buttery \\
\hline & acetoin & 15.28 & 2.9 & buttery \\
\hline & 3-methyl-1-butanol & 1.59 & 0.24 & fermented \\
\hline & butanoic acid & 0.26 & 0.02 & cheesy \\
\hline & 3-methyl-butanoic acid & 1.23 & 0.21 & sour fruity \\
\hline & $\beta$-phellandrene & 1.86 & 0.29 & minty \\
\hline & 4-methylene-1-(1-methylethyl)-bicyclo[3.1.0]hexane & 1.37 & 0.28 & woody \\
\hline & $\quad \beta$-myrcene & 0.61 & 0.05 & spicy \\
\hline & $\alpha$-phellandrene & 6.16 & 0.62 & terpenic \\
\hline & o-cymene & 2.01 & 0.27 & unknown \\
\hline & D-limonene & 13.59 & 0.88 & citrusy \\
\hline & caryophyllene & 4.15 & 0.23 & spicy \\
\hline
\end{tabular}

Note: no. 1 - hard cheese with chili flakes „L'ahké pierko s čili“; no. 2 - 6 months rippening hard cheese „Kryštálová Kamenica“; no. 3 - 3 months rippening hard cheese „Sýta Rubaň“; no. 4 - hard cheese with chives „Jemný Dubník pažítka“; no. 5 - hard cheese with 4 spices „Lahké pierko 4 korenia“.

\section{Cheese spreads aroma profile}

Processed cheese is an attractive product that enjoys great popularity. The basic raw material for processed cheese and spreads are natural cheeses and other dairy materials and non-dairy raw materials, as well as emulsifying salts (Černíková et al., 2017).

These components contribute to the aroma of the products. The aroma profile of the cheese spreads in our study was characterized by the following aromatic compounds.

Oxygen derivatives of hydrocarbons such as alcohols (represented by 2-methyl-1-butanol, 3-methyl-1-butanol, and cyclopropane-1,2,3-d3-methanol), aldehydes (2methylbutanal, 3-methylbutanal, benzaldehyde) occurred ), ketones (acetoin, 2-heptanone, 2-pentanone, 2-butanone, and 2,3-butanedione), carboxylic acids (propanoic acid, butanoic acid, hexanoic acid, octanoic acid, acetic acid, 2acetonyl-3-cyano-2,3-dimethylcyclobutane-1-carboxylic acid) and esters (ethyl butanoate and ethyl hexanoate), the nitrogen derivatives were amines (dimethylamine) and oximes (methoxyphenyloxime) and amides (butyl(formyl) formamide).

Acetoin was dominant in sample 6 with the addition of smoked cheese, followed by 2-heptanone, butyl (formyl) formamide, 2-pentanone. Sample 7 with onion flavour had the largest proportion of hexanoic acid, butanoic acid, and acetoin. 
Table 2b Cheese spreads and butter aroma profile.

\begin{tabular}{|c|c|c|c|c|}
\hline \multirow{2}{*}{ No. } & \multirow{2}{*}{ Compound } & \multicolumn{2}{|c|}{ Percentage area } & \multirow{2}{*}{ Aroma } \\
\hline & & $\overline{\mathbf{x}}$ & $S D$ & \\
\hline \multirow{10}{*}{6} & butyl(formyl)formamide & 3.33 & 2.21 & fruity \\
\hline & 2,3-butanedione & 1.53 & 0.6 & buttery \\
\hline & 2-butanone & 2.57 & 1.75 & ethereal \\
\hline & 3-methyl-butanal & 1.27 & 0.44 & aldehydic \\
\hline & 2-methyl-butanal & 0.68 & 0.37 & chocolate \\
\hline & 2-pentanone & 3.15 & 1.42 & fruity \\
\hline & acetoin & 20.4 & 6.25 & buttery \\
\hline & 2-heptanone & 6.98 & 2.06 & cheesy \\
\hline & benzaldehyde & 0.81 & 0.23 & almond \\
\hline & hexanoic acid & 1.72 & 0.96 & fatty \\
\hline \multirow{8}{*}{7} & 2,3-butanedione & 5.56 & 1.55 & buttery \\
\hline & 3-methyl-butanal & 1.02 & 0.49 & aldehydic \\
\hline & acetoin & 10.35 & 0.2 & buttery \\
\hline & butanoic acid & 19.75 & 1.47 & cheesy \\
\hline & ethyl butanoate & 2.01 & 0.24 & fruity \\
\hline & hexanoic acid & 33.65 & 5.57 & fatty \\
\hline & ethyl hexanoate & 3.07 & 0.21 & fruity \\
\hline & octanoic acid & 3.93 & 0.79 & fatty \\
\hline \multirow{10}{*}{8} & butyl(formyl)formamide & 0.85 & 0.83 & fruity \\
\hline & nitroso-methane & 4.64 & 2.3 & unknown \\
\hline & acetic acid & 4.28 & 0.87 & sour fruity \\
\hline & acetoin & 12.46 & 1.84 & buttery \\
\hline & butanoic acid & 17.77 & 1.96 & cheesy \\
\hline & ethyl butanoate & 2.06 & 0.12 & fruity \\
\hline & methoxy-phenyl-oxime & 0.85 & 0.13 & unknown \\
\hline & hexanoic acid & 34.65 & 2.24 & fatty \\
\hline & ethyl hexanoate & 2.93 & 0.58 & fruity \\
\hline & octanoic acid & 4.75 & 0.32 & fatty \\
\hline \multirow{13}{*}{9} & 2-acetonyl-3-cyano-2.3-dimethyl cyclobutane-1-carboxylic acid & 2.2 & 2.07 & unknown \\
\hline & dimethylamine & 3.09 & 0.42 & unknown \\
\hline & 2,3-butanedione & 0.83 & 0.45 & buttery \\
\hline & 2-butanone & 2.25 & 1.69 & ethereal \\
\hline & 3-methyl-butanal & 1.03 & 0.14 & aldehydic \\
\hline & 2-methyl-butanal & 1.03 & 0.66 & chocolate \\
\hline & 2-pentanone & 11.53 & 1.89 & fruity \\
\hline & acetoin & 13.28 & 1.56 & buttery \\
\hline & 2-methyl-1-butanol & 1.30 & 0.99 & roasted \\
\hline & ethyl butanoate & 1.08 & 0.32 & fruity \\
\hline & 2-heptanone & 7.59 & 1.69 & cheesy \\
\hline & methoxy-phenyl-oxime & 3.50 & 0.92 & unknown \\
\hline & hexanoic acid & 1.99 & 0.92 & fatty \\
\hline \multirow{12}{*}{10} & cyclopropane-1,2,3-d3-methanol & 8.96 & 2.29 & unknown \\
\hline & acetic acid & 8.86 & 0.63 & sour fruity \\
\hline & 3-methyl-butanal & 1.39 & 0.31 & aldehydic \\
\hline & 2-methyl-butanal & 1.76 & 0.2 & chocolate \\
\hline & propanoic acid & 21.57 & 1.87 & soury \\
\hline & acetoin & 15.60 & 0.39 & buttery \\
\hline & 3-methyl-1-butanol & 0.65 & 0.12 & fermented \\
\hline & 2-methyl-1 butanol & 1.79 & 0.5 & roasted \\
\hline & ethyl butanoate & 0.67 & 0.2 & fruity \\
\hline & 2-heptanone & 3.63 & 0.74 & cheeesy \\
\hline & methoxy-phenyl-oxime & 1.92 & 0.68 & unknown \\
\hline & ethyl hexanoate & 0.9 & 0.2 & fruity \\
\hline \multirow{3}{*}{11} & methoxy-phenyl-oxime & 5.72 & 2.86 & unknown \\
\hline & benzaldehyde & 5.96 & 3.78 & almond \\
\hline & benzyl alcohol & 7.92 & 9.07 & flowery \\
\hline
\end{tabular}

Note: no. 6 - cheese spread with smoked cheese „Syrová nátierka s údeným syrom“; no. 7 - cheese spread with onion „Syrová nátierka sladká cibul'ka“; no. 8 - cheese spread with hot paprika „Syrová nátierka pálivá paprika“; no. 9 - cheese spread with sweet paprika „Syrová nátierka dolniacka paprika“; no. 10 - cheese spread with emmental cheese „Syrová nátierka Ementálček“; no. 11 - traditional butter „Tradičné maslo“. 
Sample 8 was spicy with the addition of hot peppers, and hexanoic acid, butanoic acid, and acetoin were the most abundant. Acetoin and 2-pentanone had the largest proportion in sample 9. And in the last Emmental-flavoured sample 10, propanoic acid was the most abundant, followed by acetoin, acetic acid, cyclopropane-1,2,3-d3-methanol.

Ningtyas et al. (2019) determined flavour profile in reduced-fat cream cheese. The volatile profiles of the cream cheese contained $\beta$-glucan, esterified phytosterols, and emulsified phytosterols. Twenty-nine volatile compounds at varying levels were identified: 9 fatty acids, 9 ketones, 9 aldehydes, 2 alcohols. Additionally, high levels of acetic acid (vinegar), hexanoic acid (pungent/sour), octanoic acid, and decanoic acid (rancid/fatty) were also identified in the samples. El-Wahed and Hassanien (2019) analyzed sensory characteristics of cheese spreads and cheese spreads analogues. In control, processed cheese spread the highest concentration of major short-chain volatile fatty acids namely butyric, caproic, caprylic, and capric acids were found. Hickey et al. (2018) reported volatile compounds from the comparative study of processed Cheddar cheese. The treatment of the experimental variant lied also of buttermilk. The differences were found in the abundance of the compounds as follows: hexanol, 2-methyl-propanal, 2methyl-butanal, benzeneacetaldehyde, nonanal, butanoic acid, hexanoic acid, octanoic acid, methional, $\sigma$ decalactone.

\section{Butter aroma profile}

Butter has appreciated sensory attributes such as flavour, aroma, and melting near the body temperature, which results in a pleasant sensation in the mouth (GalindoCuspinera, Valença de Sousa and Knoop, 2017). The volatile compounds methoxyphenyloxime, benzaldehyde, and benzyl alcohol were found in our butter samples. Tamura et al. (2021) analyzed butter for volatile compounds and their contribution to fresh sweet creamy butter flavour. Out of the sixty-four identified compounds, 23 were selected, which, according to the authors, had the most significant effect on the aroma. They belonged here e.g. compounds such as $\delta$-dodecalactone, $\delta$-decalactone, $\gamma$ decalactone, acetaldehyde, and decanoic acid (capric), which were the most prominent aromatic compounds responsible for the butter flavour. Yoshinaga et al. (2019) also confirmed the presence of lactones in butter and fermented butter. The main lactones were $\delta$-decalactone, $\delta$ dodecalactone, $\delta$-tetradecalactone, $\delta$-hexadecalactone, and $\gamma$-dodecalactone. In margarine, dominant lactones were $\delta$ decalactone and $\delta$-dodecalactone. Our results, represented by benzaldehyde with a fruity aroma, benzyl alcohol with floral tones, and methoxyphenyloxime, the aroma of which is not described, do not correspond to the results of the above study.

We assume that an insufficient number of standards have influenced the identification of GC-MS compounds, so a more detailed study of the aroma profile in butter would need to take this into account, and investment in standards for compounds that have the highest probability to occur in butter should be considered.

\section{CONCLUSION}

In this paper, we evaluated selected chemical parameters (protein content, fat, dry matter, salt, and $\mathrm{pH}$ ) and sensory properties of hard cheeses, and aroma profiles of cheeses, cheese spreads, and butter of Slovak production. In general, the dry matter content was higher for ripening cheeses compared to cheeses with herbs and spices. The same trend was also confirmed for the salt content of the cheeses, where the ripening cheeses had the highest salt contents probably due to the increasing concentration of salt during the ripening process. The fat content did not follow this trend. We observed a lower $\mathrm{pH}$ in samples with herbs and ripening cheeses were characterized by a higher $\mathrm{pH}$. The protein content was relatively balanced in all samples except for the samples with the addition of chives. The consistency of the parameters measured was confirmed within the 3-month monitoring. Within the sensory panel, the sensory properties of cheese samples and cheese spreads were evaluated and the sensory acceptability of the samples was evaluated. The highest score obtained cheese with 4 spices, however, all samples were evaluated as acceptable for the consumers.

The application of sophisticated analytical methods in the study of aroma profiles of food is currently very widespread. The implementation of GC-MS and e-nose in the analysis of dairy products in the food industry consists of e.g. in the classification of products in terms of sensory properties, type, geographical origin, ripening stage (in the case of cheeses), or prediction of their durability. GC-MS and e-nos thus become powerful tools for monitoring indicators of food quality and origin. We focused on the use of the GC-MS method to evaluate the presence of volatile substances responsible for the aromatic properties of selected dairy products - cheeses, spreads, and butter of Slovak production. In general, it can be stated that the samples did not show many similarities in terms of the presence and abundance of the analyzed volatile compounds. The identified volatile compounds belonged to several chemical groups, namely oxygen derivatives of hydrocarbons such as alcohols, aldehydes, ketones, carboxylic acids, esters, amides, nitrogen derivatives such as amines, imines. Compounds from the group of terpenes, the origin of which can be attributed to plant ingredients, were also present in the samples of herbs and spices flavoured.

\section{REFERENCES}

Alinovi, M., Mucchetti, G., Tidona, F. 2019. Application of NIR spectroscopy and image analysis for the characterisation of grated Parmigiano-Reggiano cheese. International Dairy
Journal,
vol.
92 ,
p.
50-58.

Barbieri, G., Bolzoni, L., Careri, M., Mangia, A., Parolari, G., Spagnoli, S., Virgili, R. 1994. Study of the volatile fraction of Parmesan cheese. Journal of Agricultural and Food Chemistry, vol. 42, no. 5, p. 1170-1176. https://doi.org/10.1021/jf00041a023

Bertruzzi, A. S., McSweeney, P. L., Rea, M. C., Kilcawley, K. N. 2018. Detection of volatile compounds of cheese and their contribution to the flavor profile of surface-ripened cheese. Comprehensive Reviews in Food Science and Food Safety, vol. 17, no. 2, p. 371-390. https://doi.org/10.1111/1541$\underline{4337.12332}$ 
Buratti, S., Malegori, C., Benedetti, S., Oliveri, P., Giovanelli, G. 2018. E-nose, e-tongue and e-eye for edible olive oil characterization and shelf life assessment: A powerful data fusion approach. Talanta, vol. 182, p.131-141. https://doi.org/10.1016/j.talanta.2018.01.096

Capozzi, V., Lonzarich, V., Khomenko, I., Cappellin, L., Navarini, L., Biasioli, F. 2020. Unveiling the molecular basis of mascarpone cheese aroma: VOCs analysis by SPMEGC/MS and PTR-ToF-MS. Molecules, vol. 25, no. 5, p. 1242. https://doi.org/10.3390/molecules25051242

Černíková, M., Salek, R. N., Kozáčková, D., Běhalová, H., Luňáková, L., Buňka, F. 2017. The effect of selected processing parameters on viscoelastic properties of model processed cheese spreads. International Dairy Journal, vol. 66, p. 84-90. https://doi.org/10.1016/j.idairyj.2016.11.007

Delgado-Rodríguez, M., Ruiz-Montoya, M., López, R., Madejón, E., Díaz, M. J. 2012. Use of electronic nose and GC$\mathrm{MS}$ in detection and monitoring some VOC. Atmospheric Environment, vol. 51, p. 278-285. https://doi.org/10.1016/j.atmosenv.2012.01.006

Drake, M. A. 2007. Invited review: Sensory analysis of dairy foods. Journal of Dairy Science, vol. 90, no. 11, p. 4925-4937. https://doi.org/10.3168/jds.2007-0332

El-Sayed, S. M., Youssef, A. M. 2019. Potential application of herbs and spices and their effects in functional dairy products. Heliyon, vol. 5, no. 6, p. e01989. https://doi.org/10.1016/j.heliyon.2019.e01989

El-Wahed, E. M. A., Hassanien, M. F. 2019. Chemical, Rheological and Sensory Characteristics of Processed Cheese Spread Analogues. Carpathian Journal of Food Science \& Technology, vol. 11, no. 1, p. 135-148.

Galindo-Cuspinera, V., Valença de Sousa, J., Knoop, M. 2017. Sensory and analytical characterization of the "coolmelting" perception of commercial spreads. Journal of texture studies, vol. 48, no. 4, p. 302-312. https://doi.org/10.1111/jtxs. 12256

Guinee, T. P. 2004. Salting and the role of salt in cheese. International Journal of Dairy Technology, vol. 57, no. 2-3, p. 99-109. https://doi.org/10.1111/j.1471-0307.2004.00145.x

Guinee, T. P., Carić, M., Kalab, M. 2004. Pasteurized processed cheese and substitute/imitation cheese products. Cheese: Chemistry, Physics and Microbiology, vol. 2, p. 349394. https://doi.org/10.1016/S1874-558X(04)80052-6

Hamad, M. N. F., Ismail, M. M. 2013. Improvement of white cheese spread properties: 2. Adding of some flavouring agents. Journal of Food and Dairy Sciences, vol. 4, no. 5, p. 235-245. https://doi.org/10.21608/JFDS.2013.71835

Hayaloglu, A. A., Brechany, E. Y., Deegan, K. C., McSweeney, P. L. H. 2008. Characterization of the chemistry, biochemistry and volatile profile of Kuflu cheese, a mouldripened variety. LWT-Food Science and Technology, vol. 41, no. 7, p. 1323-1334. https://doi.org/10.1016/j.lwt.2007.08.020

Hickey, C. D., O'Sullivan, M. G., Davis, J., Scholz, D., Kilcawley, K. N., Wilkinson, M. G., Sheehan, J. J. 2018. The effect of buttermilk or buttermilk powder addition on functionality, textural, sensory and volatile characteristics of Cheddar-style cheese. Food Research International, vol. 103, p. 468-477. https://doi.org/10.1016/j.foodres.2017.09.081

Chen, C., Zhou, W., Yu, H., Yuan, J., Tian, H. 2020. Characterization of major odor-active compounds responsible for nutty flavor in Cheddar cheese according to Chinese taste. Flavour and Fragrance Journal, vol. 36, no. 2, p. 171-181. https://doi.org/10.1002/ffj.3627

ISO 8589. 2007. Sensory analysis - General guidance for the design of test rooms. International Standard Organisation.
Jo, Y., Benoist, D. M., Ameerally, A., \& Drake, M. A. (2018). Sensory and chemical properties of Gouda cheese. Journal of Dairy Science, 101(3), 1967-1989. https://doi.org/10.3168/jds.2017-13637

Kilcawley, K. N. 2017: Cheese Flavour. In Fox, P. F., Guinee, T. P., Cogan, T. M., McSweeney, P. L. H. Fundamentals of Cheese Science. Boston, USA : Springer, 799 p. ISBN 978-1-4899-7681-9.

Kongo, M., Malcata, F. 2015. Cheese: Processing and Sensory Properties. In Caballero, B., Finglas, P. M., Toldrá, F. Encyclopedia of Food and Health. Massachusetts, USA : Academic Press, p. 748-754. ISBN 978-0-12-384953-3. https://doi.org/10.1016/B978-0-12-384947-2.00136-7

Le Quéré, J.-L. 2011. Cheese/Cheese Flavor. In Fuquay, J. W. Encyclopedia of Dairy Sciences. Massachusetts, USA : Academic Press, 811 p. ISBN 9780123744074. https://doi.org/10.1016/B978-0-12-374407-4.00081-9

Li, Q., Yu, X., Xu, L., Gao, J. M. 2017. Novel method for the producing area identification of Zhongning Goji berries by electronic nose. Food Chemistry, vol. 221, p. 1113-1119. https://doi.org/10.1016/j.foodchem.2016.11.049

Madalozzo, E. S., Sauer, E., Nagata, N. 2015. Determination of fat, protein and moisture in ricotta cheese by near infrared spectroscopy and multivariate calibration. Journal of Food Science and Technology, vol. 52, no. 3, p. 1649-1655. https://doi.org/10.1007/s13197-013-1147-z

Manuelian, C. L., Currò, S., Penasa, M., Cassandro, M., De Marchi, M. 2017. Prediction of minerals, fatty acid composition and cholesterol content of commercial cheeses by near infrared transmittance spectroscopy. International Dairy Journal, vol. 71, p. https://doi.org/10.1016/j.idairyj.2017.03.011

Margolies, B. J., Barbano, D. M. 2018. Determination of fat, protein, moisture, and salt content of Cheddar cheese using mid-infrared transmittance spectroscopy. Journal of Dairy Science, vol. 101, no. 2, p. 924-933. https://doi.org/10.3168/jds.2017-13431

Moio, L., Addeo, F. 1998. Grana Padano cheese aroma. Journal of Dairy Research, vol. 65, no. 2, p. 317-333. https://doi.org/10.1017/S0022029997002768

Niimi, J., Eddy, A. I., Overington, A. R., Heenan, S. P., Silcock, P., Bremer, P. J., Delahunty, C. M. 2014. Aroma-taste interactions between a model cheese aroma and five basic tastes in solution. Food Quality and Preference, vol. 31, p. 19. https://doi.org/10.1016/j.foodqual.2013.05.017

Ningtyas, D. W., Bhandari, B., Bansal, N., Prakash, S. 2019. Flavour profiles of functional reduced-fat cream cheese: Effects of $\beta$-glucan, phytosterols, and probiotic L. rhamnosus. LWT, vol. $105, \quad$ p. $16-22$. https://doi.org/10.1016/j.lwt.2019.01.063

O’Callaghan, Y. C., O’Connor, T. P., O’Brien, N. M. 2017. Nutritional Aspects of Cheese. In Fox, P. F., Guinee, T. P., Cogan, T. M., McSweeney, P. L. H. Fundamentals of Cheese Science. Boston, USA: Springer, 799 p. ISBN 978-1-48997681-9.

Pérès, C., Viallon, C., Berdagué, J. L. 2001. Solid-phase microextraction-mass spectrometry: A new approach to the rapid characterization of cheeses. Analytical Chemistry, vol. 73, no. 5, p. 1030-1036. https://doi.org/10.1021/ac001146j

Poveda, M. J., Sánchez-Palomo, E., Pérez-Coello, M. S., Cabezas, L. 2008. Volatile composition, olfactometry profile and sensory evaluation of semi-hard Spanish goat cheeses. Dairy Science and Technology, vol. 88, no. 3, p. 355-367. https://doi.org/10.1051/dst:2007021

Sádecká, J., Kolek, E., Pangallo, D., Valík, L., Kuchta, T. 2014. Principal volatile odorants and dynamics of their 
formation during the production of May Bryndza cheese. Food Chemistry, vol. 150, p. 301-306. https://doi.org/10.1016/j.foodchem.2013.10.163

Schlossareck, C., Ross, C. F. 2019. Electronic tongue and consumer sensory evaluation of spicy paneer cheese. Journal of Food Science, vol. 84, no. 6, p. 1563-1569. https://doi.org/10.1111/1750-3841.14604

Smit, G., Smit, B. A., Engels, W. J. 2005. Flavour formation by lactic acid bacteria and biochemical flavour profiling of cheese products. FEMS Microbiology Reviews, vol. 29, no. 3, p. 591-610. https://doi.org/10.1016/j.fmrre.2005.04.002

Štefániková, J., Nagyová, V., Hynšt, M., Vietoris, V., Martišová, P., Nagyová, L. 2019. Application of electronic nose for determination of Slovak cheese authentication based on aroma profile. Potravinarstvo Slovak Journal of Food Sciences, vol. 13, no. 1, p. 262-267. https://doi.org/10.5219/1076

Tamura, H., Ueno, S., Naka, A., Zhao, H., Yonekura, L., Isogai, T., Wakui, R., Shiota, M. 2021. Characterisation of aroma profile and evaluation of aroma quality in sweet cream butter. International Dairy Journal, vol. 114, p. 104935. https://doi.org/10.1016/j.idairyj.2020.104935

Thomsen, M., Gourrat, K., Thomas-Danguin, T., Guichard, E. 2014. Multivariate approach to reveal relationships between sensory perception of cheeses and aroma profile obtained with different extraction methods. Food Research International, vol. 62, p. 561-571. https://doi.org/10.1016/j.foodres.2014.03.068

Tomic, O., Luciano, G., Nilsen, A., Hyldig, G., Lorensen, K., Næs, T. 2010. Analysing sensory panel performance in a proficiency test using the PanelCheck software. European Food Research and Technology, vol. 230, no. 3, p. 497-511. https://doi.org/10.1007/s00217-009-1185-y

Toro, E. E. B., Valencia, J. U. S., Molina, D. A. R. 2016. Characterization of a processed cheese spread produced from fresh cheese (quesito antioqueño). Revista Facultad Nacional de Agronomía Medellín, vol. 69, no. 2, p. 8015-8022. https://doi.org/10.15446/rfna.v69n2.59146.

Visconti, L. G., Rodriguez, M. S., Di Anibal, C. V. 2020. Determination of grated hard cheeses adulteration by near infrared spectroscopy (NIR) and multivariate analysis. International Dairy Journal, vol. 104, p. 104647. https://doi.org/10.1016/j.idairyj.2020.104647

Visioli, F., Strata, A. 2014. Milk, dairy products, and their functional effects in humans: a narrative review of recent evidence. Advances in nutrition, vol. 5, no. 2, p. 131-143. https://doi.org/10.3945/an.113.005025

Yoshinaga, K., Tago, A., Yoshinaga-Kiriake, A., Nagai, T., Yoshida, A., Gotoh, N. 2019. Effects of Heat Treatment on Lactone Content of Butter and Margarine. Journal of Oleo Science, vol. 68, no. 12, p. 1295-1301. https://doi.org/10.5650/jos.ess 19234

\section{Funds:}

This work was supported by the Slovak Research and Development Agency under the Contract no. APVV-170508 and the Contract no. APVV-19-0180.

\section{Acknowledgments:}

AgroBioTech SPU research center is greatly acknoledged for possibilty of NIR and GC-MS analysis. We would like to thank to Ing. Jana Štefániková, Ph.D., for performance of GC-MS analysis.

\section{Conflict of Interest:}

The authors declare no conflict of interest.

\section{Ethical Statement:}

This article does not contain any studies that would require an ethical statement.

\section{Contact Address:}

* PaedDr. Silvia Jakabová, PhD., The Slovak University of Agriculture in Nitra, Faculty of Biotechnology and Food Sciences, BioFood Centre, Tr. A. Hlinku 2, 94976 Nitra, Slovakia, Tel.: +421376415826,

E-mail: silvia.jakabova@uniag.sk

ORCID: https://orcid.org/0000-0002-6981-0509

Ing. Lucia Benešová, Slovak University of Agriculture in Nitra, Faculty of Biotechnology and Food Sciences, Department of Food Hygiene and Safety, Tr. A. Hlinku 2, 94976 Nitra, Slovakia, Tel.: +421 37641 4608,

E-mail: xbenesova@uniag.sk

ORCID: https://orcid.org/0000-0002-2321-6627

doc. Ing. Miroslav Kročko, PhD., The Slovak University of Agriculture in Nitra, Faculty of Biotechnology and Food Sciences, Department of Food Hygiene and Safety, Tr. A. Hlinku 2, 94976 Nitra, Slovakia, Tel.: +421 37641 4528,

E-mail: miroslav.krocko@uniag.sk

ORCID: https://orcid.org/0000-0002-4561-5573

doc. Ing. Peter Zajác, PhD., The Slovak University of Agriculture in Nitra, Faculty of Biotechnology and Food Sciences, Department of Food Hygiene and Safety, Tr. A. Hlinku 2, 94976 Nitra, Slovakia, Tel.: +421 37641 4371, E-mail: peter.zajac@uniag.sk

ORCID: https://orcid.org/0000-0002-4425-4374

Ing. Jozef Čapla, PhD., The Slovak University of Agriculture in Nitra, Faculty of Biotechnology and Food Sciences, Department of Food Hygiene and Safety, Tr. A. Hlinku 2, 94976 Nitra, Slovakia, Tel.: +421 37641 4371,

E-mail: jozef.capla@uniag.sk

ORCID: https://orcid.org/0000-0001-9475-6359

Bc. Adam Partika, Slovak University of Agriculture in Nitra, Faculty of Biotechnology and Food Sciences, Department of Food Hygiene and Safety, Tr. A. Hlinku 2, 94976 Nitra, Slovakia,

E-mail:xpartika@uniag.sk

Prof. Ing. Jozef Golian, Dr., Slovak University of Agriculture, Faculty of Biotechnology and Food Sciences, Department of Food Hygiene and Safety, Trieda A. Hlinku 2, 94976 Nitra, Slovakia, Tel.: +421 376414325 ,

E-mail: jozef.golian@uniag.sk

ORCID: https://orcid.org/0000-0001-6284-2578

Ing. Jana Štefániková, PhD., Slovak University of Agriculture in Nitra, AgroBioTech Research Centre, Trieda A. Hlinku 2, 94976 Nitra, Slovakia, Tel: +421376414911, E-mail: jana.stefanikova@uniag.sk ORCID: https://orcid.org/0000-0002-3799-4390

Corresponding author: * 